\title{
Effect of Activated Milt Residence Time on Landlocked Fall Chinook Salmon Egg Survival
}

\author{
Jessica Shannon, Nathan Huysman, Jill M. Voorhees, Eric Krebs, Michael E. Barnes \\ Department of Game, Fish and Parks, McNenny State Fish Hatchery, Spearfish, South Dakota, USA \\ Email:mike.barnes@statte.sd.us
}

How to cite this paper: Shannon, J., Huysman, N., Voorhees, J.M., Krebs, E. and Barnes, M.E. (2020) Effect of Activated Milt Residence Time on Landlocked Fall Chinook Salmon Egg Survival. Open Journal of Applied Sciences, 10, 135-141.

https://doi.org/10.4236/ojapps.2020.104011

Received: March 30, 2020

Accepted: April 17, 2020

Published: April 20, 2020

Copyright ( $) 2020$ by author(s) and Scientific Research Publishing Inc. This work is licensed under the Creative Commons Attribution International License (CC BY 4.0).

http://creativecommons.org/licenses/by/4.0/

\begin{abstract}
During artificial spawning of salmonids, activated sperm is allowed to remain in contact with eggs for variable durations. This study examined multiple residence times $(20,40,60,90$, or 120 seconds) for activated sperm on landlocked fall Chinook salmon (Oncorhynchus tshawytscha) eggs during spawning. There was no significant difference in egg survival to the eyed-stage of development or to hatch among any of the treatments, with a mean (SE) percent survival to the eyed stage of 63.9 (5.8). These results indicate that only relatively short residence times of activated milt on eggs during landlocked fall Chinook salmon spawning are needed to ensure egg survival, resulting in potentially substantial reductions in production-level spawning times and associated labor costs.
\end{abstract}

\section{Keywords}

Chinook Salmon, Oncorhynchus tshawytscha, Milt, Eggs, Spawning, Sperm

\section{Introduction}

During artificial spawning of salmonids, eggs and milt are manually removed from the fish, mixed in a pan, and water is added to initiate fertilization [1]. Sperm are inactive in milt, and only become motile upon contact with water, ovarian fluid, or other solutions [2] [3]. After activation, motile sperm can swim through the micropyle and fertilize the egg [4]. The duration of sperm motility lasts from several seconds to two minutes depending on species and other factors such as water temperature [1] [4]-[9]. To maximize the possibility of fertilization, residence times of the milt with the eggs after the addition of water have historically ranged from 2 to 15 minutes [1] [10] [11].

Landlocked fall Chinook salmon Oncorhynchus tshawytscha eggs from Lake Oahe, South Dakota exhibit extremely variable, and frequently poor, survival 
during hatchery incubation [10] [12]. In an attempt to improve spawning efficiencies and maximize egg survival, several components of the spawning process have previously been investigated [8] [13] [14]. However, the duration of milt residence times has not previously been examined. Typically, milt has been allowed to remain in contact with the eggs for two minutes after water activation [15] [16]. But, Lake Oahe salmon sperm motility ranges from 29 to 76 seconds, which is considerably less than two minutes [8]. If sperm motility has ceased before two minutes, waiting for two minutes before rinsing is unnecessary. During spawning operations involving large numbers of females, considerable time savings could be realized if the milt-egg-water residence time could be reduced. Immediately after fertilization, egg membrane separation and rapid water infusion begins (water-hardening), and egg sensitivity to shock dramatically increase [17]. It is possible that by allowing the milt and water mixture to be in contact with the eggs for two minutes, the process of rinsing the milt from the eggs at that time is contributing to egg mortality. Thus, the objective of this experiment was to investigate the effect of activated milt duration time on landlocked fall Chinook salmon egg survival.

\section{Methods}

Initial experimentation occurred at Whitlock's Spawning Station adjacent to Lake Oahe, South Dakota, USA, on October 29, 2019 using landlock fall Chinook salmon that ascended the fish ladder. Milt from individual ripe males was collected manually and stored discretely in $50 \mathrm{~mL}$ centrifuge tubes on ice until used [8]. Eggs from individual females were pneumatically removed using compressed oxygen at low pressure into a suspended net to allow the ovarian fluid to drain [14]. A sample of approximately 100 eggs was removed from the spawn and 20 eggs from this sample were then placed into each of five $13 \times 13 \times 5 \mathrm{~cm}$ (length $\times$ width $\times$ depth) plastic containers. Ten $\mathrm{mL}$ of milt was then added to each container on top of the eggs, followed by $200 \mathrm{~mL}$ of lake water $\left(8^{\circ} \mathrm{C}\right.$; total hardness as $\mathrm{CaCO}_{3}, 220 \mathrm{mg} / \mathrm{L}$; alkalinity as $\mathrm{CaCO}_{3}, 160 \mathrm{mg} / \mathrm{L} ; \mathrm{pH}$, 8.2; total dissolved solids, $440 \mathrm{mg} / \mathrm{L}$ ) for sperm activation. Five activated sperm residence time treatments were used (one per container), with rinsing of the potentially fertilized eggs occurring at 20,40,60,90, or 120 seconds after placement of the water in the container.

Rinsing occurred by pouring the container contents into a strainer to allow the excess milt and water to drain, and then gently immersing the strainer holding the eggs twice into fresh lake water. After rinsing, the eggs and approximately $500 \mathrm{~mL}$ of fresh lake water were placed into a $950 \mathrm{~mL}$ plastic bag for waterhardening and subsequent shipment for incubation. This process was repeated for eggs from 12 females, with each group of eggs from each female and treatment maintained discretely throughout the experiment.

After one hour, the water-hardened eggs were transported in coolers with ice (four hours) to McNenny State Fish Hatchery, rural Spearfish, SD, USA. After 
arrival at the hatchery, 15 eggs per bag were randomly placed into labelled (10 $\mathrm{cm})$ petri dishes containing $7 \mathrm{~mL}$ of hatchery water $\left(11^{\circ} \mathrm{C}\right.$; total hardness as $\mathrm{CaCO}_{3}, 360 \mathrm{mg} / \mathrm{L}$; alkalinity as $\mathrm{CaCO}_{3}, 210 \mathrm{mg} / \mathrm{L} ; \mathrm{pH}, 7.6$; total dissolved solids, $390 \mathrm{mg} / \mathrm{L}$ ). The petri dishes of eggs were then placed into refrigeration units (Wine Enthusiasts, Valhalla, NY; New Air, Orange County, California) and incubated at $10{ }^{\circ} \mathrm{C}$ using the techniques described by Neumiller, Blain, and Barnes [18]. Water was changed weekly during the first 28 days of incubation and then every three days thereafter [18]. Mortalities were removed in conjunction with water changes. Percent survival to the eyed stage of development (incubation day 32) and percent hatch were calculated using the following formulas:

$$
\begin{aligned}
& \text { Eye-up }(\%) \\
& =100 \times[(\text { Initial egg number }(15)-\text { Egg mortality to Day 32)/Initial egg number }] \\
& \text { Hatch }(\%)=100 \times[\text { Number of hatched fry } / \text { Initial egg number }]
\end{aligned}
$$

Because the percentage data were not normally distributed, data were analyzed using Kruskal-Wallis one-way analysis of variance with the SPSS (9.0) statistical program (IBM, Chicago, Illinois, USA). Significance was pre-determined at $\mathrm{P}<0.05$.

\section{Results}

Percent survival of the eyed stage of egg development was not significantly different among any of the fertilization treatments (Figure 1). Survival to eye up for the spawns from individual females ranged from 20 to $100 \%$, with a mean (SE) percent survival across all treatments of 63.9 (5.8). Percent survival to hatch was also not significantly different among the treatments (Figure 2).

\section{Discussion}

The results indicate that egg survival was not affected by activated sperm residence times as short as 20 seconds. This is not surprising given that the motile phase of freshwater fish sperm in general lasts less than two minutes [19]. Furthermore, the typical motile phase for Lake Oahe Chinook salmon sperm is less

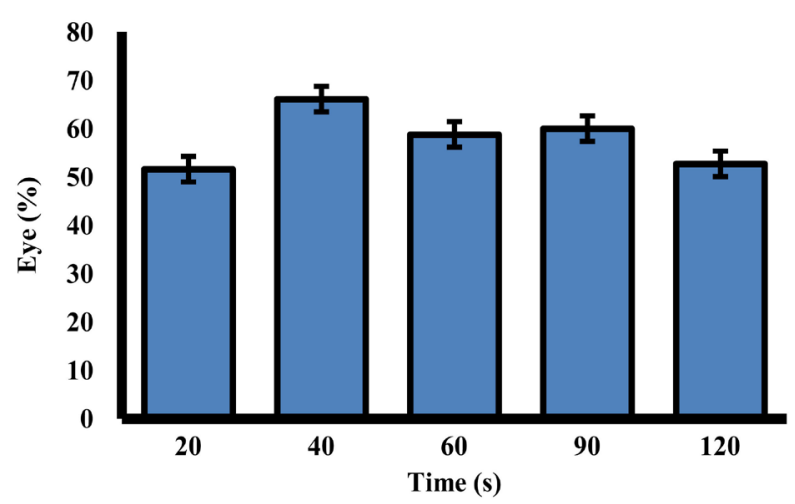

Figure 1. Mean (SE) percent survival to the eyed stage of landlocked fall Chinook salmon eggs subjected to different residence times of activated milt during spawning. 


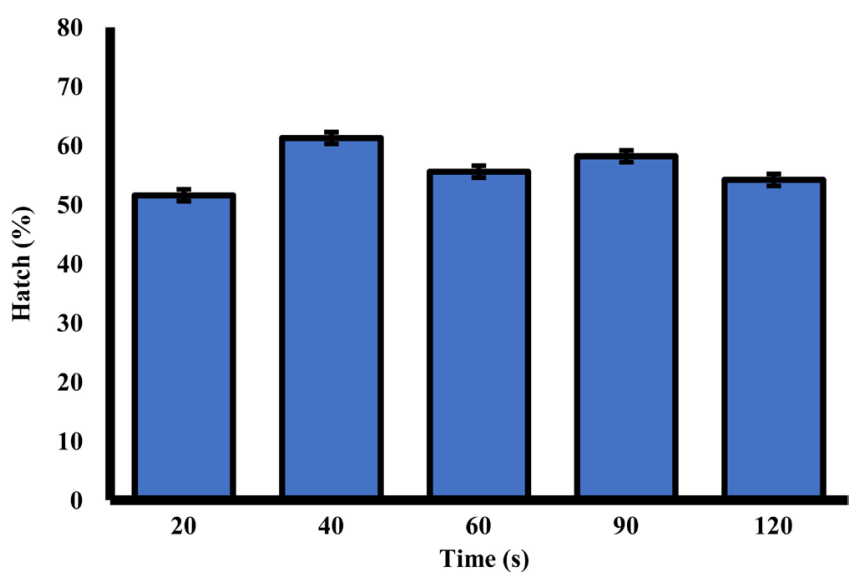

Figure 2. Mean (SE) percent survival to hatch of landlocked fall Chinook salmon eggs subjected to different residence times of activated milt during spawning.

than one minute [8], and sperm motility in other salmonid species can be even less than 20 seconds [9]. With micropyle closure occurring when the eggs are immersed in water at the same time as sperm motility is activated [7], fertilization must occur quickly.

Given the short duration of sperm motility after activation, longer sperm residence times on the eggs during artificial spawning are likely not needed. Numerous published studies and reference documents have either used, or recommend, activated milt residence times of up to 15 minutes, with two minutes somewhat established as the standard time [1] [2] [10] [11] [20] [21]. The results of this study, validating the use of residence times as short as 20 seconds, is only slightly shorter than the 30 seconds successfully used by Burrows [22]. By decreasing the amount of time between milt activation and rinsing from 120 seconds to 20 seconds, dramatic reductions in the overall time required for artificial spawning of salmonids could be realized. For example, a typical Lake Oahe Chinook salmon spawning event with 100 individual females would include 200 minutes of milt residence time using two minutes per female. By reducing milt residence times to 20 seconds per spawn, less than 34 minutes overall would be required, resulting in a time savings of nearly 90 minutes for each person involved in the spawning process.

The results of this study may have been influenced by the water temperatures used during milt activation. Salmonid sperm motility is influenced by temperature [23], with motility durations decreasing at higher temperatures [4]. Vladić and Jätrvi [24] reported that sperm motility in two salmonid species peaked near $3^{\circ} \mathrm{C}$ to $4^{\circ} \mathrm{C}$. With this study using $8^{\circ} \mathrm{C}$ water, the results should be applicable to Lake Oahe salmon spawning in more typical water temperatures of $11^{\circ} \mathrm{C}$ or greater.

It is also possible that the relative abundance of eggs and milt in this study may make these results less applicable to production-level spawning operations. While the eggs one-layer deep in the experimental containers used in this study is also normally used during the actual spawning of landlocked fall Chinook 
salmon at Whitlocks Spawning Station, the ratio of $1 \mathrm{~mL}$ of milt to 1.5 eggs is not. Rather, $50 \mathrm{~mL}$ of milt is typically used to fertilize the eggs from one female (approximately 3000) [12], or a ratio of $1 \mathrm{~mL}$ of milt to 60 eggs. Although very little milt is needed to ensure fertilization success [25], further experimentation at a larger scale is obviously needed to support the results of this study for use at a production level.

In conclusion, this study demonstrates that relatively short residence times of activated milt on eggs during landlocked fall Chinook salmon spawning are needed to ensure egg survival. While substantial reductions in production-level spawning times and associated labor could be realized by decreasing milt residence times from established norms, additional larger-scale research is warranted.

\section{Acknowledgements}

We thank Aaron Chapman, Angel Nunez, and the spawning crew at Whitlock's Spawning Station for their assistance with this project.

\section{Conflicts of Interest}

The authors declare no conflicts of interest regarding the publication of this paper.

\section{References}

[1] Piper, R.G., McElwain, I.B., Orme, L.E., McCraren, J.P., Fowler, L.G. and Leonard, J.R. (1982) Fish Hatchery Management. Department of Interior, Fish and Wildlife Service, Washington DC.

[2] Gallego, V. and Asturiano, F.J. (2019) Fish Sperm Motility Assessment as a Tool for Aquaculture Research: A Historical Approach. Reviews in Aquaculture, 11, 697-724. https://doi.org/10.1111/raq.12253

[3] Rurangwa, E., Kime, D.E., Ollevier, F. and Nash, J.P. (2004) The Measurement of Sperm Motility and Factors Affecting Sperm Quality in Cultured Fish. Aquaculture, 234, 1-28. https://doi.org/10.1016/j.aquaculture.2003.12.006

[4] Billard, R. and Cosson, M.P. (1992) Some Problems Related to the Assessment of Sperm Motility in Freshwater Fish. Journal of Experimental Zoology, 261, 122-131. https://doi.org/10.1002/jez.1402610203

[5] Christen, R., Gatti, J.-L. and Billard, R. (1987) The Transient Movement of Trout Sperm Is Related to Changes in Concentration of ATP Following the Activation of the Flagellar Movement. European Journal of Biochemistry, 166, 667-671. https://doi.org/10.1111/j.1432-1033.1987.tb13565.x

[6] Fitzpatrick J.L., Henry, J.C., Liley, N.R. and Devlin, R.H. (2005) Sperm Characteristics and Fertilization Success of Masculinized Coho Salmon (Oncorhynchus kisutch). Aquaculture, 249, 459-468. https://doi.org/10.1016/j.aquaculture.2005.02.033

[7] Ginsburg, A.S. (1963) Sperm-Egg Association and Its Relationship to the Activation of the Egg in Salmonid Fishes. Journal of Embryology and Experimental Morphology, 11, 13-33.

[8] Reese, S.E., Long, A.J., Meyer, H.A. and Barnes, M.E. (2017) Landlocked Fall Chi- 
nook Salmon Motility after Short Term Milt Storage. International Journal of Innovative Studies in Aquatic Biology and Fisheries, 3, 9-13. https://doi.org/10.20431/2454-7670.0301002

[9] Yanagimachi, R., Cherr, G N., Pillai, M.C. and Baldwin, J.D. (1992) Factors Controlling Sperm Entry into Micropyles of Salmonid and Herring Eggs. Development, Growth \& Differentiation, 34, 447-461. https://doi.org/10.1111/j.1440-169X.1992.00447.x

[10] Barnes, M.E., Hanten, R.P., Cordes, R.J., Sayler, W.A. and Carreiro, J. (2000) Reproductive Performance of Inland Fall Chinook Salmon. North American Journal of Aquaculture, 62, 203-211. https://doi.org/10.1577/1548-8454(2000)062<0203:RPOIFC >2.3.CO;2

[11] Vladić, T.V., Afzelius, B.A. and Bronnikov, G.E. (2002) Sperm Quality as Reflected Through Morphology in Salmon Alternative Life Histories. Biology of Reproduction, 66, 98-105. https://doi.org/10.1095/biolreprod66.1.98

[12] Young, K.L., Barnes, M.E. and Kientz, J.L. (2016) Reproductive Characteristics of Landlocked Fall Chinook Salmon from Lake Oahe, South Dakota. Prairie Naturalist, 48, 79-86.

[13] Huysman, N., Voorhees, J.M., Meyer, H., Krebs, E. and Barnes, M.E. (2018) Electrofishing Landlocked Fall Chinook Salmon Broodstock Negatively Impacts Egg Survival. North American Journal of Aquaculture, 80, 411-417. https://doi.org/10.1002/naaq.10058

[14] Wipf, M., Barnes, M.E. and Durben, D.J. (2011) An Evaluation of Two Egg Collection and Two Fertilization Techniques during Landlocked Fall Chinook Salmon Spawning. North American Journal of Aquaculture, 73, 339-342. https://doi.org/10.1080/15222055.2011.603966

[15] Huysman, N., Voorhees, J.M., Meyer, H., Krebs, E. and Barnes, M.E. (2019) Timing of Landlocked Fall Chinook Salmon Spawning and Egg Survival. International Journal of Aquaculture and Fishery Sciences, 5, 1-4.

[16] Krebs, W., Krebs, E., Huysman, N. and Barnes, M.E. (2018) Landlocked Fall Chinook Salmon Egg Size Is Positively Related to Hatching Time. International Journal of Pure and Applied Zoology, 6, 41-44.

[17] Jensen, J.O.T. and Alderdice, D.F. (1989) Comparison of Mechanical Shock Sensitivity of Eggs of Five Pacific Salmon (Oncorhynchus) Species and Steelhead Trout (Salmo gairdneri). Aquaculture, 78, 163-181.

https://doi.org/10.1016/0044-8486(89)90030-6

[18] Neumiller, H.K., Blain, G.A. and Barnes, M E. (2017) Incubation of Landlocked Fall Chinook Salmon Eggs in Petri Dishes. North American Journal of Aquaculture, 79, 183-186. https://doi.org/10.1080/15222055.2017.1281854

[19] Hadiseh, D., Dzyuba, B., Cosson, J., Golpour, A., Siddique, M.A.M. and Linhart, O. (2017) Effects of Water Temperature on the Physiology of Fish Spermatozoon Function: A Brief Review. Aquaculture Research, 48, 729-740. https://doi.org/10.1111/are.13049

[20] Alaska Department of Fish and Game (1983) Fish Culture Manual. Alaska Department of Fish and Game, Juneau, AK.

[21] Campbell, P.M., Pottinger, T.G. and Sumpter, J.P. (1992) Stress Reduces the Quality of Gametes Produced by Rainbow Trout. Biology of Reproduction, 47, 1140-1150. https://doi.org/10.1095/biolreprod47.6.1140

[22] Burrows, R.E. (1949) Recommended Methods for Fertilization, Transportation, and Care of Salmon Eggs. Progressive Fish-Culturist, 11, 175-178. 
https://doi.org/10.1577/1548-8640(1949)11[175:RMFFTA]2.0.CO;2

[23] Alavi, S.M.H. and Cosson, J. (2005) Sperm Motility in Fishes. I. Effects of Temperature and pH: A Review. Cell Biology International, 29, 101-110. https://doi.org/10.1016/j.cellbi.2004.11.021

[24] Vladić, T. and Jätrvi, T. (1997) Sperm Motility and Fertilization Time Span in Atlantic Salmon and Brown Trout-The Effect of Water Temperature. Journal of Fish Biology, 50, 1088-1093. https://doi.org/10.1111/j.1095-8649.1997.tb01632.x

[25] Poon, D.C. and Johnson, A.K. (1970) The Effect of Delayed Fertilization on Transported Salmon Eggs. Progressive Fish-Culturist, 32, 81-84. https://doi.org/10.1577/1548-8640(1970)32[81:TEODFO]2.0.CO;2 